\title{
APPLICATION OF ACCELERATORS IN RADIATION TECHNOLOGIES OPERATION OF AN INDUSTRIAL ELECTRON ACCELERATOR IN A DOUBLE-BEAM e,X-MODE
}

\author{
V.A. Shevchenko, A.Eh. Tenishev, V.L. Uvarov, A.A. Zakharchenko \\ National Science Center "Kharkov Institute of Physics and Technology", Kharkiv, Ukraine \\ E-mail: uvarov@kipt.kharkov.ua
}

Analysis of mixed e,X-radiation formation in output devices of an industrial electron accelerator is conducted. The possibility is demonstrated to obtain an extra radiation channel on the basis of a practically free source of Xrays simultaneously with the main channel of product processing with electron beam. The conditions of production of the secondary radiation in the state of electronic equilibrium at product treatment with scanning electron beam in the main radiation channel are studied by means of computer simulation. The dependence of spatial radiant characteristics of the X-ray radiation on the spectrum of a primary electron beam and surface density of a treated load has been established. For an industrial accelerator LU-10 of NSC KIPT, the regime of object processing in the extra radiation channel is examined. The results of calculation of the X-ray dose rate and its spatial distribution are in good agreement with the experimental data. The comparative capacity of both radiation channels of the plant is analyzed. The extra radiation source can be used for the execution of non-commercial programs like sanitation of cultural artefacts.

PACS: 87.56.bd; 41.50.+h; 81.40.Wx; 87.53Bn

\section{INTRODUCTION}

In the work [1], a concept of e,X-installation providing the possibility to use simultaneously with the product processing with scanned electron beam also the Xray radiation, accompanying this process, was stated, and a method for analysis of the path of secondary radiation formation was proposed. Such an approach enables to obtain a practically free extra source of the bremsstrahlung photons, particularly, for the sanitation of cultural artefacts (see, e.g. [2]). In the current work, the characteristics of the e,X-plant created in NSC KIPT on the basis of an industrial electron accelerator LU-10 are studied.

\section{FORMATION OF e,X-RADIATION}

It is convenient to describe the process of the electron radiation transformation into X-ray beam in various materials with wide range of their atomic number $Z=7 \ldots 73$ and electron energy $E_{0}=5 \ldots 100 \mathrm{MeV}$ in an unified form [3]. According to such an approach, the thickness of every element of the path of the secondary radiation formation along its axis is expressed in the units of range of the electrons with energy $E_{0}$ in the material of that element (the stopping thickness unit or stu). For the description of state of the mixed e,X-radiation along its path, two parameters are introduced: the energy conversion coefficient of electron radiation into bremsstrahlung photons, $\mathrm{E}_{\mathrm{x}} / \mathrm{E}_{\mathrm{b}}$, where $\mathrm{E}_{\mathrm{x}}$ is the total energy of X-rays intercepting a specified plane, normal to the radiation axis, $E_{b}$ is the electron beam energy at an accelerator output, and also the factor of the secondary radiation, $E_{x} / E_{e}$, where $E_{e}$ is the total energy of electrons intercepting that plane. So it was established, that in all cases the maximum of the conversion coefficient is reached at a depth of $\sim 0.5 \mathrm{stu}$. At further increasing of stopping length, the gradual attenuation of the photon flux takes place as a result of absorption. Maximization of the factor at a depth of $\sim 1.2$ stu corresponds to the onset of electronic equilibrium.
In case of a multicomponent exit device comprising the layers of different materials normal to the radiation axis, the stopping length of the path of the e,X-radiation formation ( from the accelerator exit window to a plane of interest) can be represented in the form

$$
S=\sum_{i} s_{i} / r_{0}\left(E_{0}, Z_{i}\right),
$$

where $S_{i}$ is the thickness of $i$-layer, $r_{0}\left(E_{0}, Z_{i}\right)$ is the electron range in its material having the atomic number $Z_{\mathrm{i}}$.

\section{LU-10 e,X-PLANT}

2.1. An industrial radiation installation LU-10 comprises a one-section electron linac with horizontal beamline (Fig. 1). The accelerator is provided with a beam scanning device $\mathrm{S}$ at its exit. The magnitude and form of the beam sweep are controlled with PC. These parameters are set up taking into account the height of an irradiated object and a specified distribution of density of the beam current on its surface.

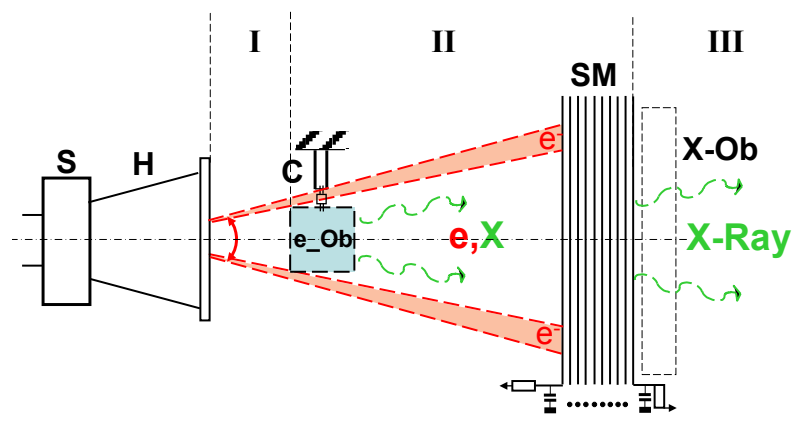

Fig. 1. Output devices of $L U-10$ accelerator

A conveyor $\mathrm{C}$ with the hook-up containers for placement of the processed load e_Ob is located at a distance of $92 \mathrm{~cm}$ from a scanner horn H. Every container has the length $L=108 \mathrm{~cm}$ The containers are distributed along the conveyor with intervals $\Delta L=12 \mathrm{~cm}$. Behind the conveyor, a wide-aperture stack-monitor SM [4] for on-line diagnostics of electron energy and absorbed dose is accommodated at a distance of $223 \mathrm{~cm}$ from the scanner horn. SM comprises a set of 10 plates 
from aluminum measured $122 \times 75 \mathrm{~cm}(\mathrm{H} \times \mathrm{W})$. The first and ultimate plates have the thickness of $5 \mathrm{~mm}$, when the 8 intermediates are $2 \mathrm{~mm}$ thick. The gaps between the plates are of $15 \mathrm{~mm}$. The stopping length of SM makes $1.2 \mathrm{stu}$ for electrons with energy of up to $10 \mathrm{MeV}$. So the bremsstrahlung radiation behind the monitor is in a state of electronic equilibrium at any surface density of the irradiated load (including its absence).

Consequently, the path of radiation formation in the LU-10 plant can be subdivided into the three areas. The first corresponds to an arbitrary pure electron beam and comprises the area between the output window of the accelerator and the front surface of the main loud (e_Ob) processed with the electron radiation. The formation of a mixed e,X-radiation takes place at a second area having stopping length of $\sim 1.2 \mathrm{stu}$. This process is completed at its rear border by reaching of condition of the electronic equilibrium. As a result, an arbitrary pure flux of X-rays, which can be used for irradiation of an additional object (X_Ob) is provided in the last third part of the radiation path.

2.2. The flux incident on the stack-monitor includes in its lower and top parts the electrons of the primary beam, when in its central part the flux of mixed e,Xradiation, generated at interaction of electron beam with the load, takes place. Consequently, the particle distribution on the surface of the stack-monitor creates a radiation shadow. The ratio of intensities of the electron and photon components in it is determined by the surface density of the object, and also by energy spectrum of the beam. In particular, at scanning of a widespectrum beam, the high-energy electrons are deviated to a lesser angle and so provide the growth of intensity of the bremsstrahlung radiation from e_Ob, and also an increase of the dose rate in the central part of $\mathrm{X} \_\mathrm{Ob}$.

Besides, the profile and intensity of the secondary radiation are variable depending on the position of a transport container relative to the beam. Thus, when a clearance between the containers passes the beam scanning zone, practically all accelerated electrons enter $\mathrm{SM}$. So the dose $\mathrm{D}^{\mathrm{x}}$ obtained by $\mathrm{X} \_\mathrm{Ob}$ can be determined from the expression

$$
D^{x}=D_{e-O b}^{x} \cdot \frac{L}{L+\Delta L}+D_{0}^{x} \frac{\Delta L}{L+\Delta L},
$$

where $D_{e-O b}^{X}$ is the dose obtained by X_Ob at the presence of e_Ob under the electron beam, $D_{0}^{X}$ is the dose obtained by X_Ob in absence of e_Ob.

\section{RESULTS AND DISCUSSION}

The conditions of product processing with the scanning electron beam in various regimes of the LU-10 plant were studied by a computer simulation technique making use a transport code GEANT4. In simulations, the load was corresponded as a parallelepiped from cellulose measuring $100 \times 35 \times 35 \mathrm{~cm}^{3}(\mathrm{X} \times \mathrm{Y} \times \mathrm{Z})$ with surface density $\rho_{\mathrm{S}}=2 ; 4 ; 6 \mathrm{~g} / \mathrm{cm}^{2}$ respectively. As a target, irradiated with the secondary X-rays (X_Ob), a plate from PMMA with lateral dimensions coincided with ones of SM and positioned behind it was considered. The beam spectra with energy in maximum $\mathrm{E}_{\mathrm{emax}}=8$ and
$10 \mathrm{MeV}$ corresponded those actually measured using a magnet analyzer (Fig. 2). In a mode with maximum of $10 \mathrm{MeV}$, the spectra having a high-energy tail (spectrum 2) and without it (spectrum 3) were used.

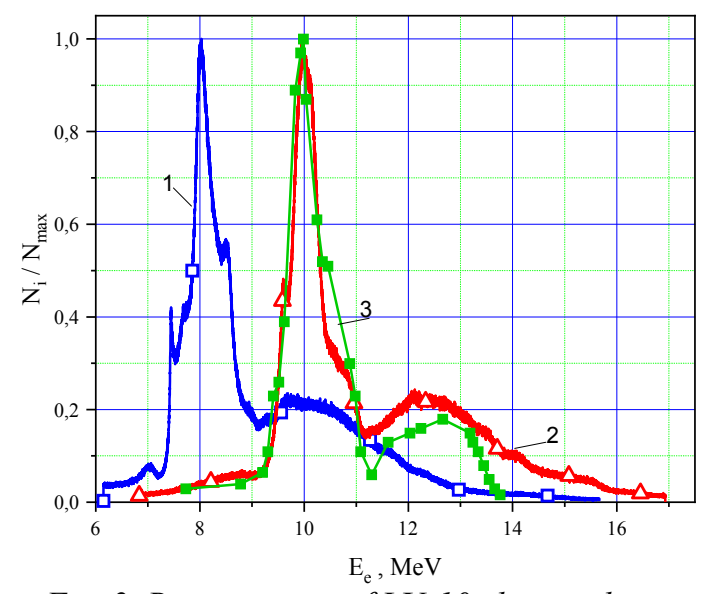

Fig. 2. Beam spectra of LU-10 electron linac

As an example, the results of calculation of the energy conversion coefficient and the secondary radiation factor along the axis of the e_Ob+SM+X_Ob system at an electron energy $\mathrm{Ee}_{\max }=10 \mathrm{MeV}$ (spectrum 3) and surface density of e_Ob, $\rho_{\mathrm{S}}=4 \mathrm{~g} / \mathrm{cm}^{2}$ are given in Fig. 3 . It is evident, that the irradiation is conducted in the conditions of electronic equilibrium.
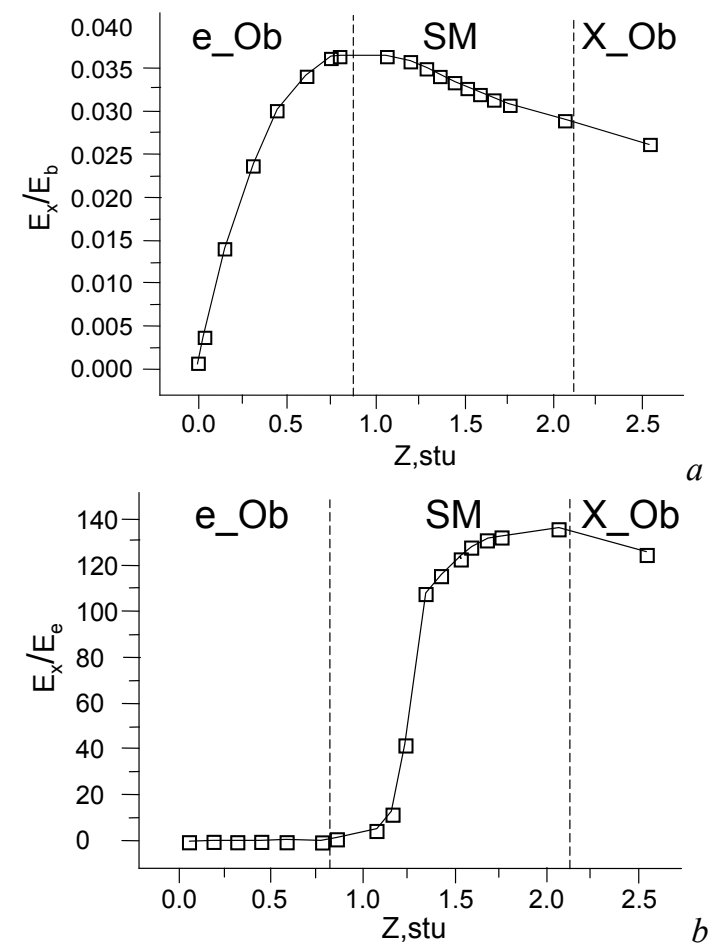

Fig. 3. Distribution of energy conversion coefficient (a) and secondary radiation factor (b) along the axis of the output devices of LU-10 installation

The characteristics of flux of the bremsstrahlung photons at the surface of $\mathrm{X}_{-} \mathrm{Ob}$ in the presence of the load e_Ob with various surface density, and also at its absence for the electron energy in maximum of the spectrum of 8 and $10 \mathrm{MeV}$ are presented in Fig. 4 and Table 1.

It is evident, that the photon energy averaged over the beam spectrum, $<\mathrm{E}_{\mathrm{X}}>$, as well as the energy conver- 
sion coefficient increase with the growth of energy of the beam electrons. At the same time, the most probable photon energy $\mathrm{E}_{\mathrm{Xmax}}$ practically keeps its value within the statistical uncertainty at the increase of surface density of e_Ob in the actual span of $2 \ldots 6 \mathrm{~g} / \mathrm{cm}^{2}$, when the conversion coefficient decreases due to the absorption of part of the photons in e_Ob. At absence of the latter, the value of the secondary radiation factor $E_{X} / E_{e}$ falls sharply.
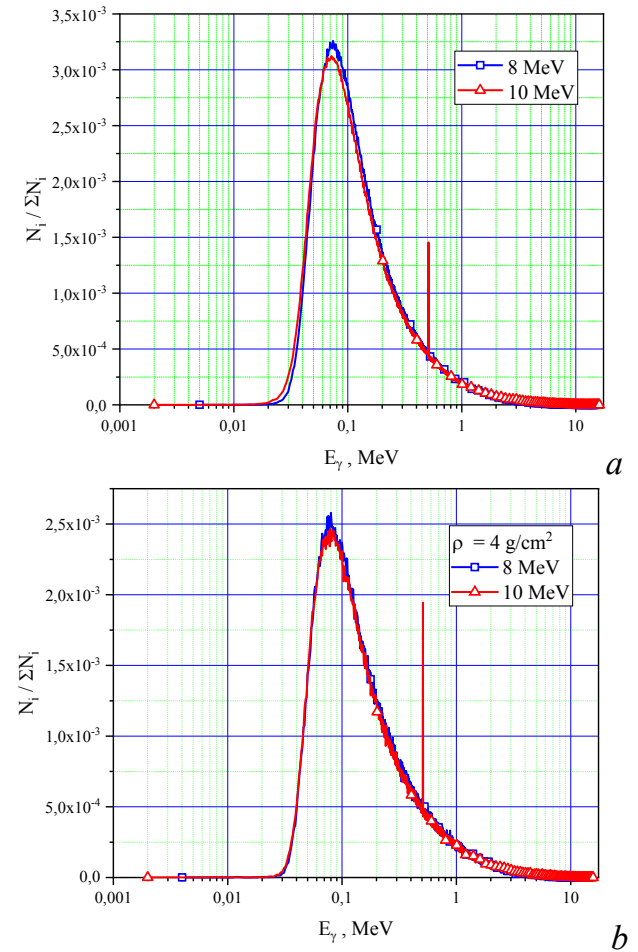

Fig. 4. Spectra of X-rays: without e_Ob (a); with e_Ob $\left(\rho_{S}=4 \mathrm{~g} / \mathrm{cm}^{2}\right)$ (b)

Table 1

Characteristics of bremsstrahlung radiation incident on $\mathrm{X} O \mathrm{Ob}$

\begin{tabular}{|c|c|c|c|c|c|c|}
\hline \multirow{2}{*}{$\begin{array}{l}\rho_{\mathrm{S}}, \\
\mathrm{g} / \mathrm{cm}^{2}\end{array}$} & \multicolumn{3}{|c|}{$8 \mathrm{MeV}$} & \multicolumn{3}{c|}{$10 \mathrm{MeV}$} \\
\cline { 2 - 7 } & $\mathrm{E}_{\mathrm{X}} / \mathrm{E}_{\mathrm{e}}$ & $\begin{array}{c}<\mathrm{E}_{\mathrm{X}}> \\
\mathrm{MeV}\end{array}$ & $\begin{array}{c}\mathrm{E}_{\mathrm{X}} / \mathrm{E}_{\mathrm{b}}, \\
\%\end{array}$ & $\mathrm{E}_{\mathrm{X}} / \mathrm{E}_{\mathrm{e}}$ & $\begin{array}{c}<\mathrm{E}_{\mathrm{X}}>, \\
\mathrm{MeV}\end{array}$ & $\begin{array}{c}\mathrm{E}_{\mathrm{X}} / \mathrm{E}_{\mathrm{b}}, \\
\%\end{array}$ \\
\hline 0 & 52 & 0.86 & 3.56 & 12 & 1.00 & 4.48 \\
\hline 2 & 163 & 0.95 & 1.54 & 150 & 1.08 & 2.27 \\
\hline 4 & 217 & 1.10 & 1.22 & 185 & 1.25 & 1.73 \\
\hline 6 & 223 & 1.18 & 1.13 & 182 & 1.35 & 1.58 \\
\hline
\end{tabular}

In Fig. 5, the distributions are presented of absorbed dose of the X-ray radiation at the surface of $\mathrm{X} \_\mathrm{Ob}$, $\mathrm{D}^{\mathrm{X}} / \mathrm{I}$, normalized to $1 \mathrm{~mA}$ of the average beam current and $1 \mathrm{~h}$ of the irradiation time for a monochromatic beam with energy of $10 \mathrm{MeV}$ acting on e_Ob and having $\rho_{\mathrm{S}}=4 \mathrm{~g} / \mathrm{cm}^{2}-(\mathrm{a})$, for a beam with actual spectrum having $\mathrm{Ee}_{\max }=10 \mathrm{MeV}$ without the high-energy part (b) and with it - (c), and also for the last version in absence of e_Ob-(d).

It is seen, that in case of a monochromatic beam (see Fig. 5,a), the vertical dose distribution has two maximums at the expense of the radiation shadow created with e_Ob. Adding the high-energy electrons results at first in leveling the dose profile (see Fig. 5,b), and then in the formation of one maximum (see Fig. 5,c,d).
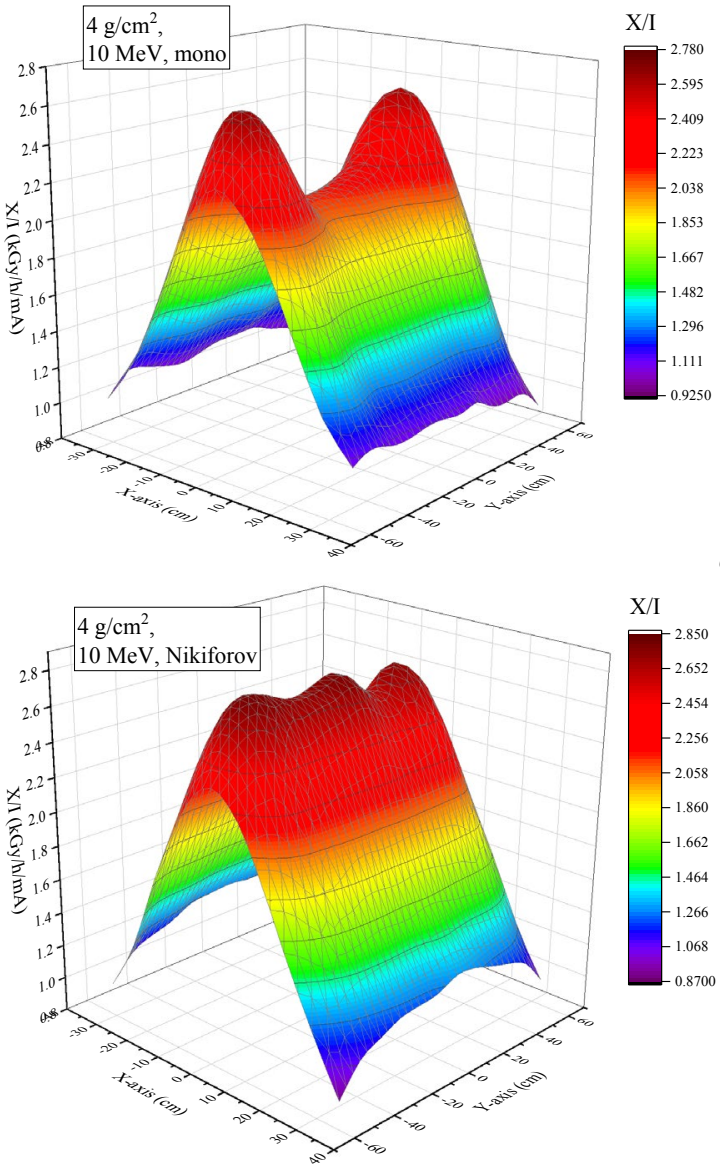

$\mathrm{X} / \mathrm{I}$

$b$

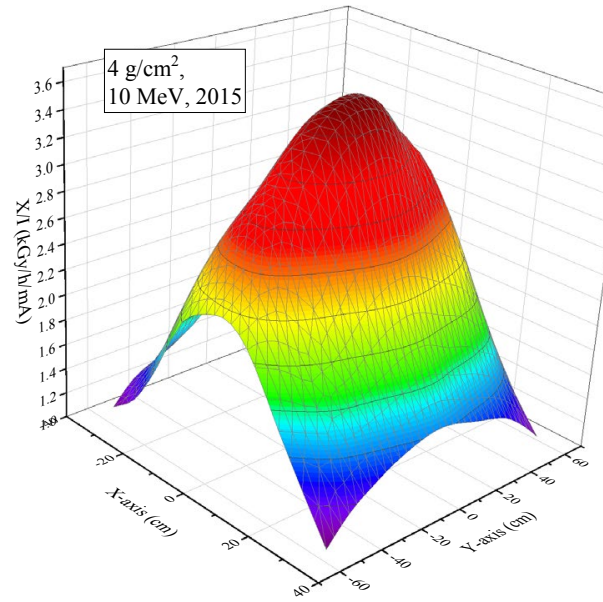

$\mathrm{X} / \mathrm{I}$
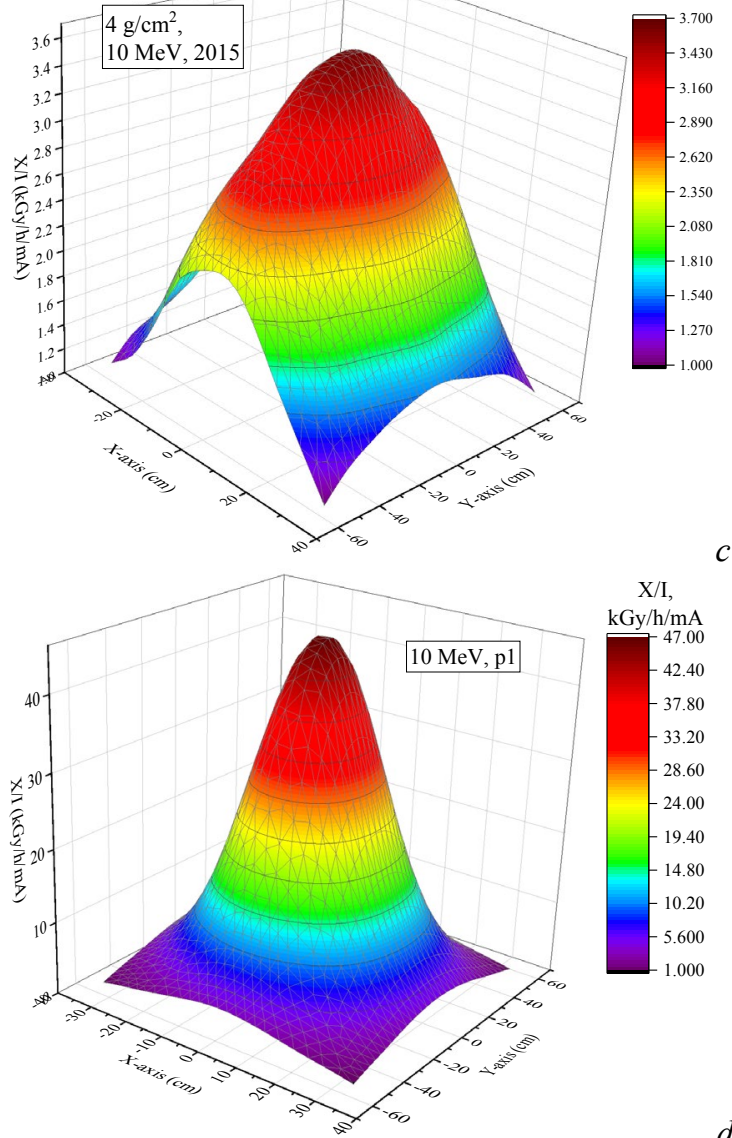

$\mathrm{X} / \mathrm{I}$
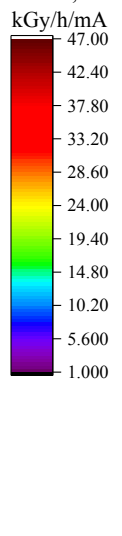

$d$

Fig. 5. Dose distribution at the surface of $X_{-} O b$ 
In Fig. 6, the normalized depth-dose distributions for $\mathrm{X} \_\mathrm{Ob}$ at a various maximum electron energy $\mathrm{E}_{\mathrm{emax}}$ and surface density of e_Ob are presented.
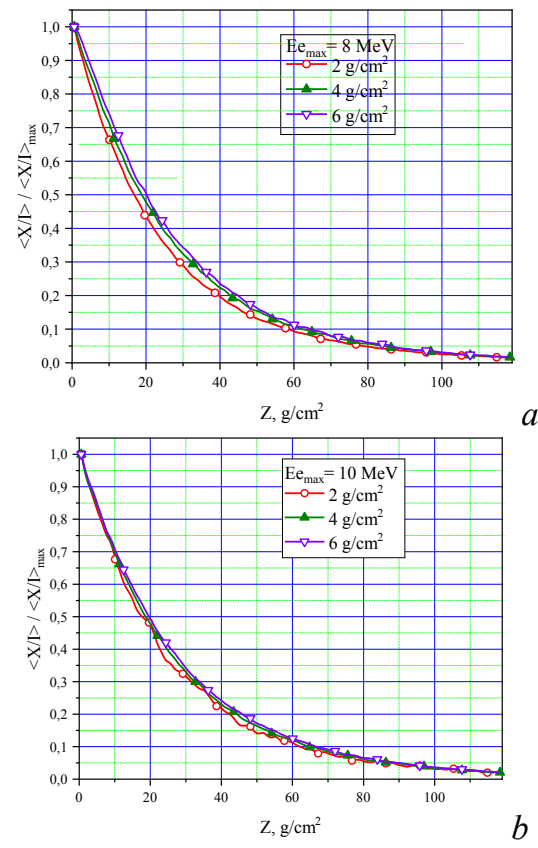

Fig. 6. Distribution of relative dose along the depth of $X_{-} O b$

It is evident, that the last parameter affects weakly on the dose distribution. The X_Ob thickness, provided the ten-fold dose reduction, Z10, appears greater than that at the use of a Ta-converter. At the same time, the dose nonuniformity at a two-sided irradiation makes $\sim 1.8$. Therefore, the Z1.5 value, providing the nonuniformity of 1.5, was calculated also (Table 2).

Table 2

Thickness of X_Ob

\begin{tabular}{|c|c|c|c|c|}
\hline \multirow{2}{*}{$\rho, \mathrm{g} / \mathrm{cm}^{2}$} & \multicolumn{2}{|c|}{$8 \mathrm{MeV}$} & \multicolumn{2}{c|}{$10 \mathrm{MeV}$} \\
\cline { 2 - 5 } & $\begin{array}{c}\mathrm{Z} 10, \\
\mathrm{~g} / \mathrm{cm}^{2}\end{array}$ & $\begin{array}{c}\mathrm{Z} 1.5, \\
\mathrm{~g} / \mathrm{cm}^{2}\end{array}$ & $\begin{array}{c}\mathrm{Z10}, \\
\mathrm{g} / \mathrm{cm}^{2}\end{array}$ & $\begin{array}{c}\mathrm{Z1.5} \\
\mathrm{g} / \mathrm{cm}^{2}\end{array}$ \\
\hline 2 & 58.9 & 47.0 & 57.7 & 47.0 \\
\hline 4 & 62.5 & 50.6 & 64.9 & 51.8 \\
\hline 6 & 66.1 & 54.1 & 67.3 & 54.1 \\
\hline
\end{tabular}

In Table 3, the results of calculation of capacity of the e,X-installation in a mode providing the average dose of 25 and $10 \mathrm{kGy}$ in the electron and X-ray radiation channels, respectively, are listed.

Capacity of e,X-plant

\begin{tabular}{|c|c|c|c|c|}
\hline \multirow{2}{*}{$\rho, \mathrm{g} / \mathrm{cm}^{2}$} & \multicolumn{2}{|c|}{$\begin{array}{c}\text { e-channel, } \\
\mathrm{kg} /(\mathrm{mA} \text {.h) }\end{array}$} & \multicolumn{2}{c|}{$\begin{array}{c}\text { X-channel, } \\
\mathrm{kg} /(\mathrm{mA} \text { ) })\end{array}$} \\
\cline { 2 - 5 } & $8 \mathrm{MeV}$ & $10 \mathrm{MeV}$ & $8 \mathrm{MeV}$ & $10 \mathrm{MeV}$ \\
\hline 2 & 509 & 515 & 33 & 67 \\
\hline 4 & 939 & 1022 & 28 & 49 \\
\hline 6 & 1051 & 1255 & 26 & 44 \\
\hline
\end{tabular}

In Fig. 7, the results of simulation and experimental study of the dose rate distribution on the rear surface of SM obtained at processing of the disposable medical attire packed in the cartons each measured $(52 \times 26 \times 26) \mathrm{cm}^{3}$ and by $4 \mathrm{~kg}$ in weight (two boxes was placed on each transport container) are presented. The isodose maps, corresponding to absence of a load and its presence, are given in Fig. 7,a,b, respectively. In the latter case, the effect of radiation shadow from the load is revealed. The results of the calculation with the use of Eq. (2) of dose distribution, corresponding to an actual treatment mode, are given in Fig. 7. The statistical uncertainty of the obtained values makes $15 \%(\mathrm{k}=1)$.
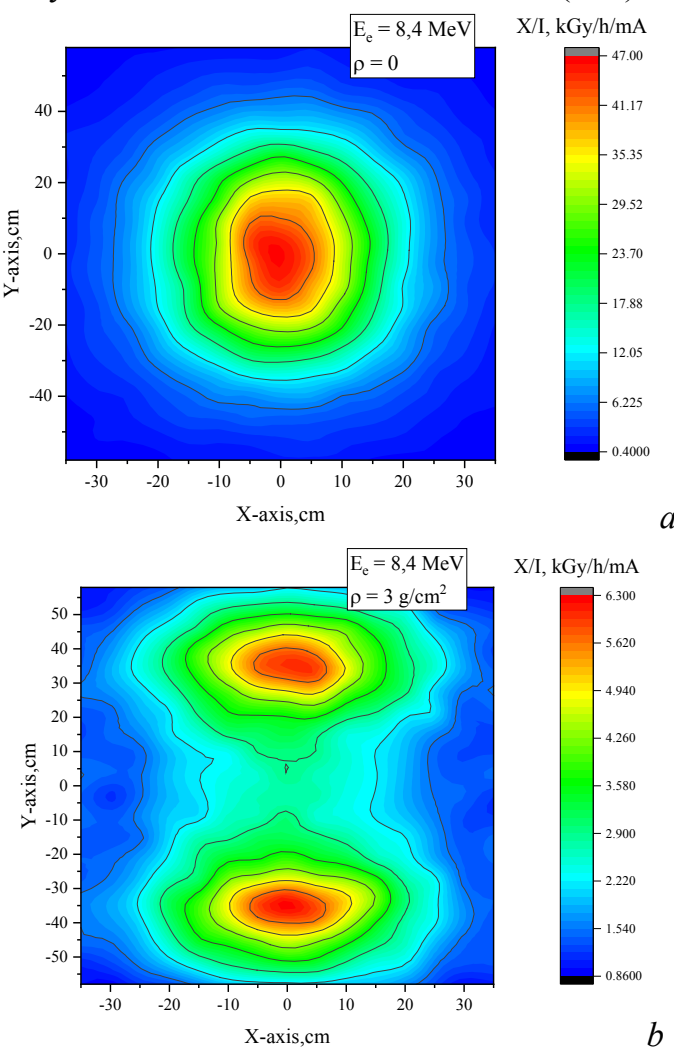

Fig. 7. Dose rate map:

$a$-in absence of $e_{-} O b ; b-a t$ the presence of $e_{-} O b$

The Harwell Red 4034 dosimetrs (Harwell Dosimeters, UK) were used for measuring the dose rate of the bremsstrahlung radiation. In Fig. 8, the calculated isodose curves at the surface of X_Ob, and also the points of the dosimeter placement (numerated) are presented.

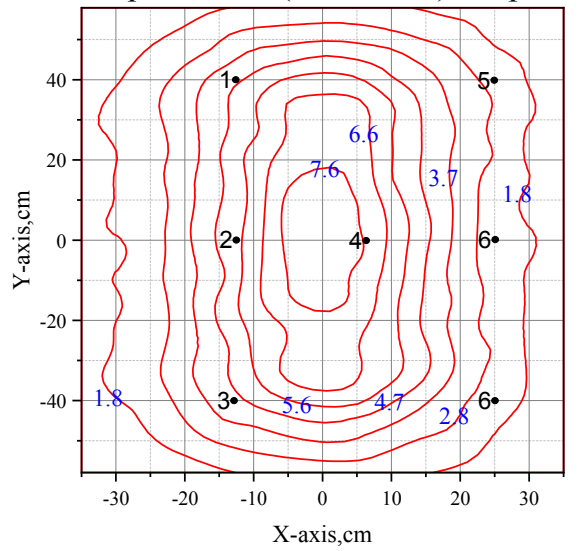

Fig. 8. Dose rate map (actual irradiation mode)

The measured values of the dose rate in the points of interest are listed in Table 4. It is evident their satisfactory agreement with the calculated data.

Table 4

Bremsstrahlung dose rate in the points of interest

\begin{tabular}{|c|c|c|c|c|c|c|c|}
\hline $\mathrm{N}_{\text {point }}$ & 1 & 2 & 3 & 4 & 5 & 6 & 7 \\
\hline$\dot{D}^{X}, \mathrm{kGy} / \mathrm{h} \cdot \mathrm{mA}$ & 3.9 & 3.5 & 3.6 & 5.8 & 1.9 & 1.5 & 2.0 \\
\hline
\end{tabular}

\section{CONCLUSIONS}


In an industrial electron accelerator with energy $8 \mathrm{MeV}$ and higher under certain conditions a free extrasource of X-rays, generated at interaction of accelerated electrons with processed product, and also with the elements of the output devices, can be obtained. In a practical range of electron energy and product surface density, the extra-source of radiation provides the possibility of treatment of various objects, in particular, cultural artifacts, having the surface density of up to $50 \mathrm{~g} / \mathrm{cm}^{2}$ and higher. The dose rate and the size of the secondary radiation field can be controlled by changing the distance to X-target. The capacity of the X-channel amounts up to $50 \mathrm{~kg} / \mathrm{kGy} \cdot \mathrm{h}$ per $1 \mathrm{~kW}$ of the electron beam power.

\section{REFERENCES}
1. V.L. Uvarov,
A.N. Dovbnya,
N.A. Dovbnya
V.I. Nikiforov. Electron Linac Based e,X-Facility //
Proc. of the EPAC 2006 Conf. 2006, p. 2257-2259.

2. Uses of Ionizing Radiation for Tangible Cultural Heritage Conservation, http:www-pub.iaea.org/MTCD/ Publications/PDF/16-17821_PUB1747_web.pdf

3. V.I. Nikiforov, V.L. Uvarov. Analysis of Mixed e,X-radiation along the Extraction Facilities of Electron Accelerators // Atomic Energy. 2009, v. 106(4), p. 281-286.

4. R.I. Pomatsalyuk, V.A. Shevchenko, A.Eh. Tenishev, D.V. Titov, V.L. Uvarov, A.A. Zakharchenko. Development of a Method of Absorbed Dose On-line Monitoring at Product Processing by Scanned Electron Beam // Problems of Atomic Science and Technology. 2016, № 3, p. 149-153.

Article received 11.10.2019

\section{ПОЛУЧЕНИЕ ДВУХПУЧКОВОГО е,Х-РЕЖИМА НА ПРОМЫШЛЕННОМ УСКОРИТЕЛЕ ЭЛЕКТРОНОВ}

\section{В.А. Шевченко, А.Э. Тенишев, В.Л. Уваров, А.А. Захарченко}

Проведен анализ условий формирования смешанного е,Х-излучения в выходных устройствах промышленного ускорителя электронов. Показана возможность получения одновременно с основным каналом облучения продукции пучком электронов дополнительного радиационного канала на основе практически бесплатного источника тормозных фотонов. Методом компьютерного моделирования изучены условия получения вторичного излучения в состоянии электронного равновесия при проведении обработки продукции сканирующим пучком электронов в основном радиационном канале. Получена зависимость пространственноэнергетических характеристик тормозного излучения от спектра первичного пучка электронов и поверхностной плотности обрабатываемого им груза. Для промышленного ускорителя ЛУ-10 ННЦ ХФТИ исследованы условия обработки объектов в дополнительном радиационном канале. Результаты расчета мощности дозы тормозного излучения и ее пространственного распределения удовлетворительно согласуются с измеренными в эксперименте. Получены данные по сравнительной производительности установки в обоих радиационных каналах. Дополнительный источник излучения может быть использован для проведения некоммерческих программ (например, санитарной обработки объектов культурного наследия).

\section{ОДЕРЖАННЯ ДВОПУЧКОВОГО е,Х-РЕЖИМУ НА ПРОМИСЛОВОМУ ПРИСКОРЮВАЧІ ЕЛЕКТРОНІВ}

\section{В.А. Шевченко, А.Е. Тєнішев, В.Л. Уваров, О.О. Захарченко}

Проведено аналіз умов формування змішаного е,Х-випромінювання у вихідних пристроях промислового прискорювача електронів. Показана можливість отримання одночасно з основним каналом опромінювання продукції пучком електронів додаткового радіаційного каналу на основі практично безкоштовного джерела гальмівних фотонів. Методом комп'ютерного моделювання вивчені умови отримання вторинного випромінювання в стані електронної рівноваги при проведенні обробки продукції скануючим пучком електронів в основному радіаційному каналі. Отримана залежність просторово-енергетичних характеристик гальмівного випромінювання від спектра первинного пучка електронів і поверхневої щільності оброблюваного ним вантажу. Для промислового прискорювача ЛУ-10 ННЦ ХФТІ досліджені умови обробки об'єктів у додатковому радіаційному каналі. Результати розрахунку потужності дози гальмівного випромінювання та ії просторового розподілу задовільно узгоджуються із зміряними в експерименті. Отримані дані з порівняльної продуктивності установки в обох радіаційних каналах. Додаткове джерело випромінювання може бути використане для проведення некомерційних програм (наприклад, санітарної обробки об'єктів культурної спадщини). 